\title{
Non-Timber Forest Products Trade and Community Livelihoods around Mabira Central Forest Reserve, Uganda
}

\author{
Tugume Patience (Corresponding author) \\ Dept. of Plant Sciences, Microbiology and Biotechnology, Makerere University \\ P.O Box 7062, Kampala, Uganda \\ Tel: 256-772 484289 E-mail:ptugume@cns.mak.ac.ug/patiebeys@ gmail.com \\ Buyinza Mukadasi, \& Namaalwa Justine \\ College of Agriculture and Environmental Sceinces, Makerere University \\ P.O Box 7062, Kampala, Uganda \\ Tel: $256-772-515366$
}

Tel: +256-772-962877

Kakudidi Esezah, Mucunguzi Patrick, \& Kalema James

Dept. of Plant Sciences, Microbiology and Biotechnology Makerere University

P.O Box 7062, Kampala, Uganda

Maud Kamatenesi-Mugisha

Bishop Stuart University

P.O Box 1, Mbarara, Uganda

Tel: 256-772-438905

Received: May 23, 2016 Accepted: June 2, $2016 \quad$ Published: September 11, 2016

doi:10.5296/jas.v4i4.9482ＵRL: http://dx.doi.org/10.5296/jas.v4i4.9482

\begin{abstract}
This paper generates data on the diversity and value of non- timber forest products (NTFP) traded in markets adjacent to Mabira Central forest reserve. The objective of the study was to evaluate the contribution of NTFP trade to the livelihoods of traders' households. Quarterly market surveys and field observations were conducted in eleven markets in 2014. All NTFP
\end{abstract}


traders were interviewed using semi structured questionnaires. Simple profitability method was used to determine the profit margins of the traded products. The per capita value of NTFP traded was calculated and was highest for drums $(\$ 3,101)$ and lowest for winnowing trays (\$3). All products had profit margins above 60\%. Income generated from NTFP was used to cater for other essential needs like payment of school fees, medical treatment, buying food and other household items. NTFP trade has potential of improving the lives of traders through establishment of NTFP enterprises. In order for such enterprises to be successful traded forest products must be harvested sustainably to ensure consistent supply of the products. Multipurpose species like Markhamia lutea, Phoenix reclinata, Raphia farinefera and Calamus sp could be domesticated to minimize pressure on the forest.

Keywords: Market, per capita value, multipurpose species, profitability, income, Mabira, livelihood

\section{Introduction}

Non-Timber Forest Products (NTFP) are traded in the local and regional markets in most of the developing countries. These markets are growing as new products enter the market, on top of the existing trade. The expansion is driven by both supply and demand factors (Murthy, Bhat, Ravindranath, \& Sukumar, 2005; Shackleton, Shackleton, Buiten, \& Bird, 2007), increasing integration, market economy and the need for home based incomes (Barany, Hammett, Leaky, \& Moore, 2005). Until recently, timber products derived from sawn timber, wood chips, wood based panel and pulp have been considered as the major sources, or even most important forest products due to their income generating capacity (Ngane et al., 2012). NTFP were regarded to be of minor or of secondary importance (Makon, Ngatou, \& Ndikumagenge, 2005); and thus were not given much attention. The importance of NTFP has increased considerably, through use within households and generation of income (Ndoye \& Tieguhong, 2004). NTFP have become an important source of sustainable cash income for people living in or near forests (Shackleton, Shanley, \& Ndoye, 2007). The utilisation of NTFP provides an incentive for participatory forest management (Belcher \& Schreckenberg, 2007; Belcher, 2005) and a possible solution to relieve the local people of the dependence on timber. NTFP thus play an important role both in forest conservation and improvement of livelihoods for forest dwellers.

Trade in NTFP significantly contributes to community and household economies. Despite this trade accounting for the bulk of local sales, NTFP markets tend to be poorly acknowledged or appreciated as contributors to rural livelihoods and are often neglected when valuing forests. Limited recognition of NTFP is attributed to insufficient knowledge regarding their importance and value. Statistical data on NTFP values at the national level are usually incomplete and not comparable between countries (Agea et al. 2011; Croitoru, 2007). There is little information on NTFP traded in the rural markets and the only focus has been on products traded in formal markets (Mahapatra \& Tewari, 2005). Studies have concentrated on products procured for export markets (Claudio, 2005) but this may not be important in terms of contribution to the rural income and employment of local people living adjacent to forests.

The functioning of local NTFP markets could be an important tool for the identification of 
commonly used species that need to be conserved in addition to identifying profitable secondary products from NTFP processing that could form a basis of the development of NTFP enterprises. Willem te Velde et al. (2006) confirms that studies on local marketing are indispensable for sound conservation and development planning.

In Uganda, NTFP studies explored aspects of documentation (Asiimwe, Namutebi, Borg-Karlsson, Kamatenesi-Mugisha, \& Oryem-Origa, 2014; Namukobe et al. 2011), market surveys for individual plant species (Agea, Katongole, Waiswa, \& Nabanoga, 2008; [National Environmental Management Authority, NEMA, 2011]) and plants known and used in homes (Agea et al. 2013; Tabuti, 2007), missing investigations on a variety of NTFP sold in local markets. As a result, a large portion of NTFP escapes formal markets a situation that causes economic and environmental challenges. The missing knowledge on sales volumes, supply and demand of different NTFP is very critical especially in the face of increasing rates of deforestation in the country [Uganda Bureau of Statistics, (UBOS, 2011)]. Lack of such information could result into deforestation due to the search for alternative land uses, or may lead to the exploitation of specific NTFP species resulting into resource depletion or environmental damage. Information regarding marketable NTFP is necessary for communities to make optimal and sustainable use of the forest resource. This study aimed at generating information on the importance of NTFP in livelihoods of communities adjacent to Mabira CFR. The specific objectives were to; (i) Document the NTFP traded and (ii) Evaluate the contribution of NTFP trade to the livelihoods of traders' households.

Understanding the benefits that accrue from NTFP trade can help traders to develop informed business strategies to optimize returns from forest resources. The study identifies profitable products as a target for promotion of small enterprises. Multipurpose species used to manufacture high value products which are traded in high volumes and thus susceptible to overexploitation are identified targeted for conservation or possible domestication.

\section{Materials and Methods}

\subsection{Study Area}

Mabira Central Forest Reserve (CFR) lies partly in Buikwe, Mukono and Kayunga districts and occupies an area of $306 \mathrm{~km}^{2}$ with an altitudinal range of $1070-1340 \mathrm{~m}$ above sea level. It is situated between latitude $0^{\circ} 22^{\prime}$ and $0^{\circ} 35^{\prime}$ and between longitude $32^{\circ} 56^{\prime}$ and $33^{\circ} 02^{\prime} \mathrm{E}$ (Figure 1). 


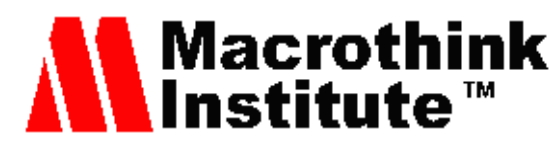

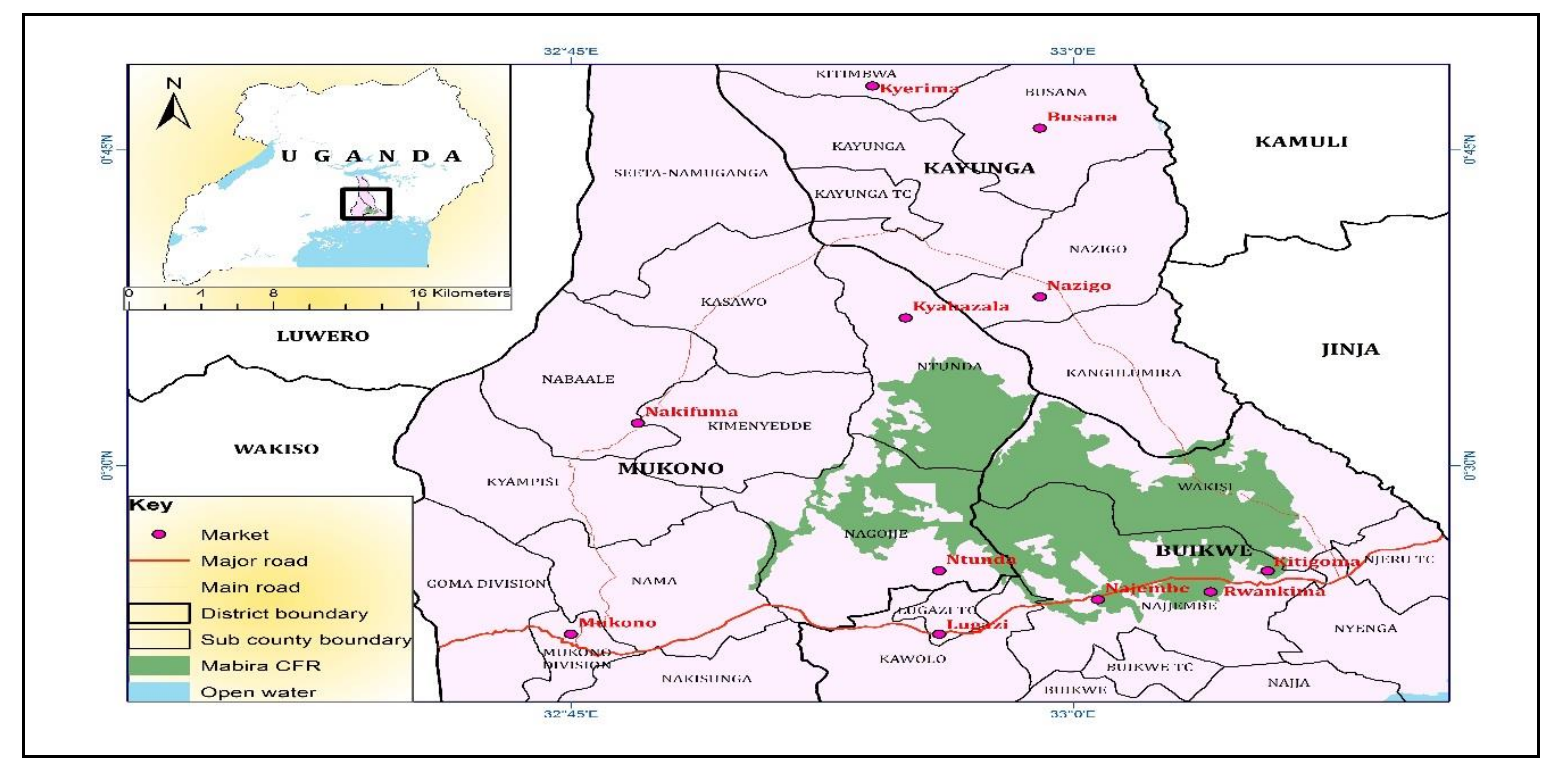

Fig. 1. Location of study sites (markets) adjacent Mabira CFR, highlighting the major administrative boundaries and markets where surveys were conducted.

\subsection{Research Design}

This study was based on a general survey design. The research was conducted through a market survey of NTFP traders in eleven markets where forest products were traded (Figure. 1). Both qualitative and quantitative approaches were used to gather the required data. Market surveys, key informant interviews and field observations were used for data collection. Village leaders provided information that guided the process of mapping and classifying markets thus providing information on which markets to visit. Eleven markets were selected to fulfil the criteria of NTFP availability on market days. Classification of the markets was based on their nature whether periodic or permanent and NTFP traded such that proper planning for the surveys was achieved. With their consent, all the vendors selling NTFP were counted. The vendors were sampled after a clear explanation of the purpose of the study and research objectives; and having agreed to participate. All vendors that participated in the study were remunerated for their time by paying them a nominal fee. Due to the likely differences between wet season and dry season in the production of forest products, surveys were done in the same markets every season corresponding to the four quarters of 2014. A total of 60, 46, 40 and 42 traders were interviewed pro-rata during the four quarters of the year respectively.

\subsection{Data collection}

The procedures of data collection were according to Martin (1995). The study commenced with a reconnaissance survey in all the identified markets. This was intended to pretest the questionnaires, gain rapport and build trust among the NTFP traders. Data were collected from eleven markets within the villages surrounding Mabira CFR. A native local language speaker was engaged as the Research Assistant during the data collection period (Tabuti, Dhillion, \& Lye, 2003). The markets surveyed included: Nazigo, Busana, Rwankima, Kitigoma, Mukono, Kyerima, Nakifuma, Ntunda, Kyabazala, Lugazi and Najjembe all within a distance of $500 \mathrm{~m}$ to $6 \mathrm{Km}$ from the forest reserve. By walking around the market, a variety 
of NTFP traded were noted and a short interview conducted with each seller, using a semistructured questionnaire consisting of both open ended and close ended questions administered in the local Luganda language and in English to the few non-Luganda speakers. Face to face interviews were augmented with key informant interviews which allowed in depth understanding of market operations. Direct observations of NTFP found on the market stalls helped to confirm the results of key informant interviews. The following information was sought during the interviews, product traded, raw material used, quantity sold per week and price per unit. Vendors provided information on source of the products, how availability of raw materials has changed over years and the costs incurred in the course of trade. The sale of NTFP excluded medicinal plants which are normally sold in specialized places.

All NTFP offered for sale by each vendor were counted according to the local unit of measurement (bundles, bags, units) in order to establish the amount of the product available for sale on the market day. The average market price of each product was multiplied with the calculated volumes for each product to establish the value of the products at the time of sampling (Van Andel, Behai-Randos, Itavinga, \& Groenendijk, 2007). From this data, volumes of NTFP offered for sale per vendor, percentage of stalls selling individual products, and subsequently the value of NTFP and total supply of the product available at the time of the market survey were established. The per capita value of each NTFP was calculated basing on the total value of each NTFP and the number of traders selling the product in each quarter; and the average per capita values calculated for the four quarters.

\subsection{Data Analysis}

The value of NTFP traded was calculated by the formulae $\mathrm{V}=\mathrm{p} \times \mathrm{q}$; where $\mathrm{V}$ is value, $\mathrm{p}$ is price and $\mathrm{q}$ is the quantity sold. $\mathrm{NV}=\mathrm{TV}-\mathrm{C}$ where $\mathrm{NV}$ is net value; $\mathrm{TV}$ is Total Value; $\mathrm{C}$ is costs incurred. Costs included transport, labour, taxes and raw materials. Labour cost referred to the amount of money incurred in processing products and collection of raw materials from the forest. The labour cost was considered to be the number of hours used in resource collection/product processing multiplied by the value of labour hour within the study area. The number of hours dedicated to NTFP related activities was established from interviews. The cost of labour was assessed as being equivalent to the amount of money that could be earned from agricultural labour. Agriculture being one of the few alternative economic activity available in the study area was used to estimate the cost of labour. From discussions with participants a figure of approximately three thousand Uganda shillings (Shs 3,000 $\equiv \$ 1$ ) per hour was estimated. The NTFP values were converted to United States dollars using the average dollar rate of (USD = UGX 2,530; 2548; 2622; 2728 for the first, second, third and fourth quarters respectively; according to the Bank of Uganda (BOU) monetary statements of 2014. NTFP were categorized under cluster names, and Simple Profitability Method was used to determine their profit margins (De Caluwe, 2011) using the formula $P M=\frac{\mathrm{SP}-(\mathrm{PP}+\mathrm{OC})}{\mathrm{SP}} \times 100 \%$ where $\mathrm{PM}=$ profit margin, $\mathrm{PP}=$ purchase price, $\mathrm{SP}=$ Selling price and $\mathrm{OC}=$ operational cost. Per capita value of traded products was calculated.

\section{Results}

\subsection{Value of marketed NTFP}

NTFP traders play an important role in providing market outlets for primary collectors; and 
distribution of products to final consumers. The value of NTFP also depends on the volumes available on the market at the time of the survey. Like any other traded product, the prices of NTFP were influenced by the forces of supply and demand. In times of high demand like festive season, beginning of school terms and cultural ceremonies, the price of mats, brooms, barkcloth and drums, increased. Moreover, other factors that influenced the price of NTFP were season, quality, harvesting costs, cost of raw materials and bargaining power of consumers. The per capita value of NTFP amounted to $\$ 9,181$. Drums had the highest per capita value followed by racks, charcoal, chairs and mats. Winnowing trays had the lowest per capita value (Table 1).

Table 1. Per capita value of traded NTFP $(1 \$=$ Shs 2,600$)$

\begin{tabular}{|c|c|c|c|c|c|}
\hline NTFP & $\begin{array}{l}\text { No. of } \\
\text { Traders }\end{array}$ & $\begin{array}{c}\text { Total per } \\
\text { capita } \\
\text { income }(\$)\end{array}$ & NTFP & $\begin{array}{l}\text { No. of } \\
\text { Traders }\end{array}$ & $\begin{array}{c}\text { Total per } \\
\text { capita } \\
\text { income }(\$)\end{array}$ \\
\hline Drums & 2 & 3101.152 & Tube fiddle & 1 & 96.19708 \\
\hline Racks & 2 & 999.0586 & Hats & 1 & 89.29392 \\
\hline Charcoal & 4 & 884.6344 & Raffia strings & 1 & 77.09659 \\
\hline Chairs & 1 & 608.7971 & Tables & 1 & 70.94652 \\
\hline Mats & 13 & 496.2055 & Flower vases & 1 & 68.64989 \\
\hline Firewood & 5 & 334.7621 & Money purse & 1 & 62.65602 \\
\hline Serving mats & 2 & 312.863 & Mingling sticks & 5 & 54.23559 \\
\hline Stools & 3 & 288.822 & Shakers & 1 & 37.23876 \\
\hline Motor \& Pestle & 2 & 212.2673 & Raffia skirts & 2 & 31.41243 \\
\hline Baskets & 7 & 206.237 & Bag & 1 & 30.23263 \\
\hline Baby cots & 2 & 198.3308 & Rattan bundles & 2 & 28.88103 \\
\hline Brooms & 2 & 187.9721 & Fruits & 1 & 21.87649 \\
\hline Bark cloth & 1 & 164.5477 & Rattan canes & 1 & 21.64903 \\
\hline Xylophone & 2 & 135.5215 & Tool handles & 2 & 20.21123 \\
\hline Lamp shade & 1 & 121.4123 & Flute & 1 & 10.3022 \\
\hline Bow harp & 1 & 107.3229 & Winnowing trays & 1 & 3.162055 \\
\hline Palm leaves & 8 & 96.96882 & & & \\
\hline
\end{tabular}

The rate $1 \$=$ Shs 2,600 was the average exchange rate for the periods of the survey. The per capita value of each NTFP was calculated based on the total value of each NTFP and the number of traders selling the product in each quarter. Average per capita values were calculated for the four quarters. The number of traders is the average of traders found in the markets at the time of the survey.

An analysis of quarterly values of NTFP presented some variations. The value was highest in the first quarter $(\$ 76,691)$ and lowest in the third quarter $(\$ 43,215)$. The value of NTFP in the second and fourth quarters amounted to $\$ 71,215$ and $\$ 47,037$ respectively. All the traded NTFP categories were profitable with profit margins of above $60 \%$ (Table 2 ). 
Table 2. Profit Margins of a Variety of NTFP Traded

\begin{tabular}{lcccc}
\hline \hline NTFP category & $\begin{array}{c}\text { Average sales } \\
\text { revenue at time } \\
\text { of survey }(\$)(\mathrm{a})\end{array}$ & $\begin{array}{c}\text { Mean cost } \\
(\$)(\mathrm{b})\end{array}$ & $\begin{array}{c}\text { Net Profit }(\$) \\
(\mathrm{c})\end{array}$ & $\begin{array}{c}\text { Profit } \\
\text { margin }(\%) \\
(\mathrm{d})\end{array}$ \\
\hline Bark cloth & $1,710.27$ & 118.18 & $1,592.1$ & 93.1 \\
Raffia strings & $18,394.52$ & $1,687.65$ & $16,706.87$ & 90.8 \\
Musical Instruments & $103,452.22$ & $4,257.21$ & $99,196.61$ & 87.2 \\
Domestic handicraft & $103,184.46$ & $8,549.02$ & $37,056.15$ & 84.6 \\
Household items & $12,390.83$ & $1,432.67$ & $10,958.16$ & 82.2 \\
Firewood & $46,201.54$ & $9,145.38$ & $37,056.15$ & 80.2 \\
Palm leaves & $15,530.22$ & $3,218.65$ & $12,311.57$ & 79.3 \\
Simple furniture & $35,754.82$ & $6,347.67$ & 29,407 & 67.0 \\
Charcoal & $49,002.62$ & $18,032.62$ & $30,970.00$ & 63.2 \\
\hline
\end{tabular}

$\mathrm{d}=\mathrm{c} / \mathrm{a} * 100 \%, \mathrm{c}=\mathrm{a}-\mathrm{b}$

Musical instruments included tube fiddles, flutes, bow harps, drums and shakers. Household items included winnowing trays, motors and pestles, mingling sticks, tool handles, flower vases and brooms. Handicrafts included raffia skirts, mats, baskets and hats. Furniture included racks, chairs, stools and tables. Some products like palm leaves, charcoal, firewood and bark cloth were not classified under any group due to their uniqueness and volumes available.

\subsection{Use of NTFP income in traders households}

NTFP traders in all markets utilised the generated income to meet the basic household needs in addition to other expenditures. NTFP income was used to buy food, clothes, pay medical bills, school fees, and purchase scholastic materials. In some cases NTFP income was used as startup capital for other income generating activities which diversifies the livelihood options of NTFP traders thus reducing the risk of NTFP dependence. Women traders use NTFP income to acquire raw materials used in the production of handicrafts. For instance the purchase of artificial dyes used to colour palm leaves and Raphia strings used in production of mats and baskets respectively is done using NTFP income. The use of artificial dyes resulted from the decrease in species of Holoptelea grandis that was originally used as a source of natural dye. Women who mainly sold crafts reported that they were able to process the products (weaving mats and baskets) they traded in from their homes; in between other household chores.

\subsection{Non-financial Benefits of Mabira CFR to Adjacent Communities}

Traders were aware of the environmental benefits offered by Mabira CFR that necessitate its conservation such as acting as a source of water for domestic use and its importance in rainfall formation. Some respondents also observed that Mabira CFR has a high potential for generating income from tourism value due to its rich biodiversity. 


\section{Discussion}

The high levels of profitability from NTFP trade point to the fact that the value obtained from NTFP was considerable and formed a monetary base for people involved in the activity. A high profit margin of $89 \%$ was earlier recorded for wild foods and medicinal plants in Uganda (Barirega, Tabuti, \& Van Damme, 2012). The high levels of returns generate capacity for the NTFP traders to cater for their other household needs. Shackleton and Shackleton (2005) and (Schreckenberg, Marshall, Newton, Rushton, \& Edouard, 2006) illustrated similar findings about financial returns from NTFP trade. A high return from NTFP trade was also reported in Uganda (Barirega et al. 2012). High profits from NTFP trade may attract more players in the activity. However as more people get attracted, multipurpose species may become prone to overharvesting leading to degradation of the forest resource. Some of the multipurpose species used in the production of at least eight products each were: Markhamia lutea, Phoenix reclinata, Raphia farinefera and Calamus sp. As demand for products made from these species increase, there is a likelihood of degradation and ultimate reduction in species abundance or extinction altogether. Rattan (Calamus sp) which is used in the production of six items has already reduced in abundance and rattan traders and carpenters are progressively being forced to use other materials like the vines of Alchornea cordifolia.

Processed products like drums and mats were more valuable compared to unprocessed ones. The high value of mats is attributed to both high volumes and a high number of traders. High charcoal values are attributed to the escalating prices of the product resulting from high demand in urban centres in Central Uganda. These findings are related to other studies in Ethiopia (Lemenih, Abebe, \& Olsson, 2003), Cameroon (Ndam, 2004) and India (Singh, Bhattachaya, Vyas, \& Roy, 2010). The study suggests that drum and mat production have potential of being developed to a large scale in order to generate incomes for the rural poor as long as raw materials are available. Charcoal and firewood are on high demand in Uganda as common sources of cooking (NEMA, 2011). The high demand for the products translates into high values. Arnold, Kohlin, and Persson (2006) reported firewood and charcoal as the main sources of household energy in many cities of the developing world. Despite the high value, extraction of firewood and charcoal is destructive and threatens the long term sustainability of the forest ecosystem and in the long run the livelihood of the rural poor who depend on the forest for other forest products. Since trade in all NTFP was profitable, dependence on firewood and charcoal can be minimized by shifting to trade in other NTFP whose harvesting have minimum negative impact on the forest resource. This can only be achieved if cheap alternative sources of energy are availed to the rural poor who cannot afford using electricity to divert their dependence on the forest for charcoal and firewood to alternative sources.

The low value and supply of fruits is an indication that the use of forest foods is dwindling as people gain more access to purchased foods. Other indicators could be the penetration of rural markets by new products and changing tastes. Unlike in other studies where forest foods were important to the rural people (Pfoze, Kumar, Sheikh, \& Myrbor, 2012; Tiruneh \& Herbert, 2008) the current sturdy reported contrary results because wild edible plants were scarce. This can also reflect reduced indigenous knowledge levels about wild edible plants in the area. In addition, as the value of labour rises with increasing wealth, the opportunity cost of gathering rather than purchasing forest foods becomes higher because of long distances 
that have to be travelled to collect scarce foods and this drives away people from wild food gathering.

The high per capita value of drums, charcoal, racks and mats indicates that traders in these products obtain higher values from trade compared to traders selling other products. This may drive more people into harvesting big volumes of the raw materials used to process such products in a bid to benefit from the high values. However to be commercially successful, NTFP must have a permanent market guaranteed by a consistent supply of the product. This can be attained if there is sustainable harvesting of products from the forest. This means that resource extraction should not have any long-term harmful effects on regeneration rates of species harvested or ecosystem structures and functions.

The high profitability of traded NTFP is a sign of operational efficiency. Profits from NTFP sales can be reinvested in other business ventures; or used to expand the existing business. These will reduce market risks through diversification and ensure long term business viability respectively. The fact that some traders are able to achieve reasonable incomes suggests that products traded in rural markets may have more potential as revenue earners than is sometimes assumed.

Selective harvesting of plant species preferred for making multiple products and those with high value may be accelerated. This will overtime cause a shift in the composition of the remaining forest stock to the less demanded/desired species. Some studies have revealed a positive relationship between low biodiversity and high NTFP profitability (Vodouche, Coulibaly, Assogbadjo, \& Sinsin, 2008). On the other hand a downward shift in the demand of forest products could reduce pressure on the forest resource and promote species diversity and abundance. A downward shift in demand is attainable provided substitutes for traded NTFP are availed at cheaper prices affordable to the rural poor otherwise the practical solution would be sustainable harvesting. The ecological impact of extraction depends intensely on the nature of the harvested product. Harvesting plant parts like fruits and seeds may have a smaller impact than harvesting the bark, roots, trunk; or the entire plant. In this study the highly valued products involve harvesting trunks and entire plants which is likely to reduce the abundance of used species if sustainable harvesting is not practiced. On the other hand, a decrease in competition due to a lessened density of individual plant species can sometimes stimulate growth of invasive species like Broussonetia papyrifera that was abundant in forest gaps resulting from tree felling for charcoal and firewood. In general, therefore, extraction should be in balance with the reproductive rate of species.

\section{Conclusion}

NTFP trade can generate cash income that is important for the improvement of livelihoods of households by meeting basic needs especially food, medicine, school fees and other expenditures. Drums, racks, charcoal, chairs and mats had high per capita values which make them favourable subjects for establishment of NTFP enterprises. This however needs to be approached with caution, because of the negative effects their unsustainable harvesting is likely to have on the forest. This can only be supported if domestication of commonly used species is promoted in order to reduce pressure on the forest, while sustaining income from 
harvesting less destructive forest products. Increased research in finding ways to domesticate multipurpose NTFP species is thus instrumental. Recognition of non-financial benefits of Mabira CFR by some traders can be a motivation to involve them in conservation activities to safe guard the integrity of the forest.

\section{Acknowledgement}

We are grateful to African Development Bank for funding the research. We thank the NTFP traders in the surveyed markets for providing us with the required data during the survey. We are also grateful to our Research Assistant, Catherine Twesiime and field guide Abdul Kasozi for the assistance rendered during data collection.

\section{References}

Agea, J. G., Katongole, B., Waiswa, D., \& Nabanoga, G. N. (2008). Market survey of Mondia Whytei (Mulondo) roots in Kampala city. African Journal of Traditional Complimentary and Alternative Medicine, 5(4), 399-408.

Agea, J. G., Okia, C. A., Kimondo, J. M., Woiso, D. A., Obaa, B. B., Obua, J., . . . Teklehaimanot, Z. (2013). Harvesting, preparation and preservation of commonly consumed wild and semi-wild food plants in Bunyoro-Kitara Kingdom. International Journal of Medicinal and Aromatic Plants., 3(2), 262-282.

Agea, J. G., Okia, C. A., Abohassan, J. M., Kimondo, J. M., Obua, J., Hael, J., \& Teklehaimanot, T. Z. (2013). Wild and semi-wild food plants of Bunyoro Kitara Kingdom of Uganda: Growth forms, Collection niches, parts consumed, consumption patterns, main gatherers and consumers. Environmental Research Journal, 5(2), 74-86.

Arnold, M., Kohlin, G., \& Persson, R. (2006). Woodfuels, Livelihoods and Policy Interventions: Changing perspectives. World Development, 34(3), 596-611.

Asiimwe, S., Namutebi, A., Borg-Karlsson, A., Kamatenesi-Mugisha, M., \& Oryem-Origa, H. (2014). Documentation and Consensus of Indigenous Knowledge on Medicinal Plants Used by the Local Communities in Western Uganda. Journal of Natural Products Plant Resources, $4(1), 34-42$.

Barany, M., Hammett, A. L., Leaky, R. R. B., \& Moore, K. M. (2005). Potential income generating opportunities for small holders affected by HIV/AIDS: Linking agro-ecological change and non timber forest product markets. Journal of Management Studies, 39, 26-39.

Barirega, A., Tabuti, R. S., \& Van Damme, P. (2012). Potential commercialisation and value chain improvement of wild foods and medicinal plants in Uganda. Journal of Biological Sciences, 4(2), 108-116.

Belcher, B., \& Schreckenberg, K. (2007). Commercialisation of forest products: A reality check. Development Policy Review, 25, 355-377.

Belcher, B. M. (2005). Forest product markets, forests and poverty reduction. International Forestry Review, 7(2), 82-89. 


\section{Mll Macrothink}

Journal of Agricultural Studies

ISSN 2166-0379

2016, Vol. 4, No. 4

Camou-Guenero, A., Reyes-Garcia, V., Martinez-Ramos, M., \& Casas, A. (2008). Knowledge and use value of plant species in Raramuri Community: A Gender perspective for conservation. Human Ecology, 36, 259-272.

Claudio, O. D. (2005). Not Just Minor forest products: The Economic rationale for the consumption of wild food plants by subsistence farmers. Ecological Economics, 58, 64-73.

Croitoru, L. (2007). Valuing the non- timber forest products in the mediterranean region. Ecological Economics, 63(4), 768-775.

De Caluwe, E. (2011). Market chain analysis of boabab (Adansonia digitata L.) and Tamarind (Tamarindus indica L.) products in Mali and Benin. (PhD), Ghent University, Ghent, Belgium.

Heubach, K., Witting, R., Nuppenau, E., \& Hahn, K. (2011). The economic importance of non-timber forest products (NTFP) for livelihood maintenance of rural West African communities: A case study from northern Benin. Ecological Economics, 70, 1991-2001.

Lele, S., Pattanaik, M., \& Rai, N. D. (2010). NTFP in India: rhetoric and reality. In S. A. Laird, R. J. Mclain \& R. P. Wynberg (Eds.), Wild products governance: Finding policies that work for NTFP (pp. 85-111). London: EartnScan.

Lemenih, M., Abebe, T., \& Olsson, M. (2003). Gum and resin resources from some Acacia, Boswellia and Commiphora species and their economic contributions in Liban, south-east Ethiopia. 55, 465-482. J. Arid Environ., 55, 465-482. http://dx.doi.org/ 10.1016/50140-1963(3)00053-3.

Mahapatra, A. K., \& Tewari, D. D. (2005). Importance on non timber forest products in the economic valuation of dry deciduous forests of India. Forest Policy and Economics, 7, 455-467.

Makon, M., Ngatou, D., \& Ndikumagenge, C. (2005). Bilan et analyse des experiences de partenariants en gestion forestiere dans le Bassin Congo. Paper presented at the Confrence on central African moist forest ecosystems., Younde, Cameroon.

Martin, G. J. (1995). Ethnobotany: A methods manual. London: Chapman \& Hall.Murthy, I. K., Bhat, P. R., Ravindranath, N. H., \& Sukumar, R. (2005). Financial Valuation of Non-timber forest product flows in Uttara Kannada District,Western Ghat, Karnataka. Current Science, 88(10), 1573-1579.

Namukobe, J., Kasenene, J. M., Kiremire, B. T., Byamukama, R., Kamatenesi-Mugisha, M., Krief, S., . . Kabasa, J. D. (2011). Traditional plants used for medicinal purposes by local comminities around the Northern sector of Kibale National Park, Uganda. Journal of Ethnopharmacology, 136, 236-245.

Ndam, N. (2004). Prunus africana: a traditional medicine finds international fame. In: C. Julius, Ndoye, O. (Eds.) (Ed.), Development of Trade and Marketing of Non-wood Forest Products for Poverty Alleviation in Africa. A Report Prepared for the Project. Lessons Learnt on Sustainable Forest Management in Africa. Regional Office for Central and West Africa, 
BP, Messa:: Center for International Forestry Research (CIFOR).

Ndoye, O., \& Tieguhong, J. C. (2004). Forest Resources and rural livelihoods. The conflict between timber and non timber forest products in the Congo Basin. Scans. Forest Resources, $19,36-44$.

NEMA. (2011). Contribution of the Forestry Sub-sector to the National Economy: The Economic value of forest resources of Uganda. Kampala.

Ngane, B. K., Ngane, E. B., Sumbele, S. A., Njukeng, J. W., Ngone, M. A., \& Ehabe, E. E. (2012). Seasonality of Non-timber forest products in the Kupe Mountain region of South Western Cameroon. Scientific Research and Essays, 17(18), 1786-1797.

Paumgarten, F., \& Shackleton, C. M. (2009). Wealth differentiation in household use and trade in non-timber forest products in South Africa. Ecological Economics, 68(12), 2950-2959. doi: http://dx.doi.org/10.1016/j.ecolecon.2009.06.013

Pfoze, N. L., Kumar, Y., Sheikh, N., \& Myrbor, B. (2012). Assessment of local dependence on selected wild edible plants and fruits from Senapati district, Manipur, North Eastern India. Ethnobotany Research \& Applications., 10, 357-367.

Schreckenberg, K. E., Marshall, A., Newton, D. W. L., Rushton, J., \& Edouard, F. (2006). Commercialisation of NTFP: What determines success? London: London Overseas Development Institute (ODI).

Shackleton, C. M., \& Shackleton, S. E. (2006). Household wealth status and natural resource in the Kat valley, South Africa. Ecological Economics, 57(2), 306 - 317.

Shackleton, C. M., Shackleton, S. E., Buiten, E., \& Bird, N. (2007). The importance of dry woodlands and forests in rural livelihoods and poverty alleviation in South Africa Forest Policy and Economics, 9, 558-572.

Shackleton, S., Shanley, P., \& Ndoye, O. (2007). Invisible but viable: recognising local markets for non-timber forest products. International Forestry Review, 9(3).

Sills, E. O., Shanley, P., Paumgarten, F., de Beer, J., \& Pierce, A. (2011). Evolving perspectives on Non-Timber Forest Products. In S. E. Shackleton, C. M. Shackleton \& P. Shanley (Eds.), Non timber forest products in the global context. (pp. 23-51). Hiedelberg: Springer.

Singh, A., Bhattachaya, P., Vyas, P., \& Roy, S. (2010). Contribution of NTFP in the livelihood of Mangroove Forest dwellers of Sundarban. Journal of Human Ecology, 29(3), 191-200.

Tabuti, J. R. S. (2007). Status of non-cultivated food plants in Bulamogi County, Uganda. African Journal of Ecology, 45(1), 96-101.

Tabuti, J. R. S., Dhillion, S. S., \& Lye, K. A. (2003). Traditional medicine in Bulamogi county, Uganda: Its practitioners, users and viability. Journal of Ethnopharmacology, 85, 119-129. 


\section{Macrothink}

Journal of Agricultural Studies

ISSN 2166-0379

2016, Vol. 4, No. 4

Tiruneh, F. M., \& Herbert, H. (2008). Wild Edible fruit species cultural domain, informant species competence and preference in three districts of Amhara region, Ethiopia. Ethnobotany Research and Applications, 6, 487-502.

UBOS. (2011). Statistical Abstarct 2011. Kampala.

Van Andel, T., Behai-Randos, J., Itavinga, R., \& Groenendijk, S. (2007). The medicinal plant trade in Suriname. Ethnobotany Research and Applications, 5, 351-372.

Vodouche, F. G., Coulibaly, O., Assogbadjo, A. E., \& Sinsin, B. (2008). Medicinal plant commmercialisation in Benin; an analysis of profit distribution equity across supply chain actors and its effect on the sustainable use of harvested species. J. Medicinal Plants Research, 2, 331-340.

Willem te Velde, D., Rushton, J., Schreckenberg, K., Marshall, E., Edouard, F., Newton, A. C., \& Arancibia, E. (2006). Entrepreneurship in value chains of non-timber forest products. Forestry Policy and Economics, 8, 725-741.

\section{Copyright Disclaimer}

Copyright for this article is retained by the author(s), with first publication rights granted to the journal.

This is an open-access article distributed under the terms and conditions of the Creative Commons Attribution license (http://creativecommons.org/licenses/by/3.0/). 